\title{
Determinant of Financial Structure Decision in Small and Medium Enterprises: A Pilot Study of Selected Registered Companies in Nigeria
}

\author{
${ }^{1}$ Akingunola, Richard and ${ }^{2}$ Oyetayo, Oluwatosin \\ Department of Banking and Finance, Faculty of Management Sciences, Olabisi Onabanjo University, Nigeria \\ Department of Economics, Accounting and Finance, College of Management Sciences, Bells University of \\ Technology, Nigeria
}

\begin{abstract}
In the world of corporate finance, financial structure decision of firms remains one of the most critical. Previous empirical studies have identified factors like size, asset structure, tangibility, profitability, risk, growth and market-to-book ratio all of which have been exhausted in literature as determinants of financial structure of firms. However, research on verifying the existence of these factors in small size firms has been minimal. This study presents a sample of SMEs in Nigeria which serves as a pilot survey for the test of the existence and strength of the identified determinant factors of financial structure. A panel data of ten firms for five years was analyzed using the pooled OLS. The result reveals profitability and size as the only determinant factor for firms under study. This shows a deviation from other studies on small firms in developing economies, the reason which may be country specific. The study provides a starting point for a more inclusive and comprehensive study on financial structure decisions of SMEs in Nigeria.
\end{abstract}

Key words: financial structure, small sized firms, determinant factors, pilot study

\section{Introduction}

Financial structure is one of the most prolific areas of research in business finance. Extensive research over the past fifty (50) years has yielded little conclusive guidance for managers choosing between debt and equity in financing their firms.

Abar and Biekpe (2005) pointed out that more than fifty percent of the assets of firms are financed by debt and that there is acorrelation between debt ratio and firm size, growth, asset, tangibility, risk and corporate tax. Given the unique financial features of small and medium enterprises depending on the environment in which they operate, there are strong grounds for a separate study in financial structure determinants of small and medium enterprises.

One of the paradoxes of modern management is the technical and social change which is so pervasive and rapid, that it seems to be out of pace with the rhythms of nature. To cope with this flux-trend of unpredicted business environment, a company needs to capitalize on internal strength, take advantages of external opportunities and mitigate internal weaknesses (Loghojofor 2000)

Business organizations in Nigeria like their counterparts elsewhere have continued to operate in a rather volatile and highly competitive environment. The reality of the challenge posed by changes in this environment is so wide. These changes are in many respects discontinuous. Nigeria as country has over sixty percent $(60 \%)$ of her total business organizations operating on the scale of small and medium enterprises. Over the years, the problem of these small and medium enterprises has been 'lack of funds'. Government on its part has continued to seek for various means and schemes to channel funds to small and medium enterprises all to no avail. Recent researches conducted on Nigerian businesses reveals that the problem of small and medium enterprises is more with their understanding of financial management principles, techniques and correct application than the availability of funds (Ezeoha, 2008)

One of the key issues in financial management that small and medium companies need to be more sensitive to is their financial structure. Failure of financial managers to choose an optimal financial structure for their organizations has caused such firms great loss in financial structure expenditure and maintenance. A research on financial structure presents an opportunity to verify the applicability of some of the most popular theories of financial structure in a country setting with a novel dataset.

Some of the notable works on capital structure decision of small firms, Phlaktis et.al (2010) show that among other factors, small firms employ higher levels of leverage as the economy grows faster and income increases. They increase debt maturities as the economy becomes more stable with reduced inflation and interest rates

The overall objective of this study therefore is to empirically access the determinants of financial structure decision for small and medium enterprises from the context of a developing country by including more 
firm variables apart from the size effect. It is expected that this study will reveal if there are peculiar factors that determine the financial structure decision of small and medium sized companies, the extent, the association among the determining factors and the leverage of these companies.

The remainder of this paper is organized as follows; Section 2 presents Review of concepts, theories and empirical studies on capital structure decisions both in developed and developing countries, large, small and medium sized companies. Section 3 focuses on data and methodology. Section 4 discusses the empirical results while Section 5 concludes the paper.

\section{Theoretical and conceptual Issues}

The term capital structure relates to the proportion of different types of securities both debt and equity issued by a company. Owualah (1998) mentioned that an optimal capital itself one where the mix of these proportions creates a financial structure from a company that maximizes its potential value for the owners. There are no hard and fast rules in setting an optimal capital. The financial manager has two concerns in this area. First, how much should he borrow? That is, what mixture of debt and equity is best? The mixture chosen will affect both the risk and the value of the firm. Secondly, what are the least expensive sources of fund for the firm? in order words, what percentage of the firm's cash flow goes to creditors and what percentage goes to shareholders. A company with a large proportion of fixed interest capital is said to be highly geared, while a company with a low proportion of fixed interest capital is said to be lowly geared.Fixed interest stockholders enjoy a lower degree of risk than ordinary shareholders, since they have prior right to repayment of capital in the event of company being wound up.Because of the lower risk, the cost of fixed interest capital is lesser. If the rate of return on the firm's investment exceeds the cost of fixed interest capital, there is an advantage in introducing certain amount of gearing or leverage into the financial structure of the firm. Moreover, it has been widely demonstrated in the literature of business finance that debt is a cheaper source of capital than equity (tending to reduce the firm's cost of capital), because interest is deductible for income tax purposes.

$\mathrm{T}$ herefore when firm's borrow at an interest rate below the return at which the funds are to be invested, thereby increasing the percentage return on equity, the use of fixed charges sources of funds such as debt and/or preference capital along with the owners' funds/equity in the financial structure is described as financial leverage or 'trade on equity'

\subsection{Review of theories on Determinants of financial structure Decisions 2.1.1 Size}

There are several theoretical reasons why firm size would be related to the capital structure. Smaller firms may find it relatively more costly to resolve informational asymmetries with lenders and financiers, which discourages the use of outside financing (Chung, 1993; Grinblatt and Titman, 1998) and should increase the preference of smaller firms for equity relative to debt (Rajan and Zingales, 1995). However, this problem may be mitigated with the use of short term debt (Titman and Wessels, 1988). Relative bankruptcy costs and probability of bankruptcy (larger firms are more diversified and fail less often) are an inverse function of firm size (Pettit and Singer, 1985; Titman and Wessels, 1988). A further reason for smaller firms to have lower leverage ratios is that smaller firms are more likely to be liquidated when they are in financial distress (Ozkan, 1996).

\subsubsection{Asset structure}

The degree to which the firms' assets are tangible and generic should result in the firm having a greater liquidation value. By pledging the assets as collateral (Myers, 1977; Harris and Raviv, 1990) or arranging so that a fixed charge is directly placed to particular tangible assets of the firm, also reduces adverse selection and moral hazard costs (Long and Malitz, 1992). Bank financing will depend upon whether the lending can be secured by tangible assets (Storey, 1994; Berger and Udell, 1998). Tangible assets could also have a negative impact on financial leverage by augmenting risk through the increase of operating leverage (Hutchinson and Hunter, 1995).

Part of the intangible assets, such as reputation, becomes quasi-tangible and interpreted by debt holders as a guarantee (Balakrishnan and Fox, 1993). Liquidity ratios may have a mixed impact on the capital structure decision. Companies with higher liquidity ratios might support a relatively higher debt ratio due to greater ability to meet short-term obligations. On the other hand firms with greater liquidities may use them to finance their investments. Therefore the companies' liquidities should exert a negative impact on its leverage ratio (Ozkan, 2001). Moreover the liquid assets can be used to show the extent to which these assets can be manipulated by shareholders at the expense of bondholders (Prowse, 1990). 


\subsubsection{Tangibility}

When firms are able to pledge their assets as collateral, investment and borrowing become endogenous; pledgeable assets support more borrowings that in turn allow for further investment in pledgable assets. Credit multiplier has an important impact on investment when firms face credit constraints: investment-cash flow sensitivities becomes increasing in the degree of tangibility of constrained firms. Therefore tangibility is influencing whether a firm is classified as credit constrained or unconstrained in a switching regression framework.

\subsubsection{Profitability}

There are conflicting theoretical predictions on the effects of profitability on leverage. Following the POT, profitable firms, which have access to retained profits, can use these for firm financing rather than accessing outside sources. (Kester, (1986); Baskin, (1989); Griner and Gordon (1995); Sunder and Myers (1999). Jensen, (1986) predicts a positive relationship between profitability and financial leverage if the market for corporate control is effective because debt reduces the free cash flow generated by profitability. From the TOT point of view (Marsh (1982); Rajan and Zingales (1995); Chittenden et al. (1996), more profitable firms are exposed to lower risks of bankruptcy and have greater incentive to employ debt to exploit interest tax shields.

\subsubsection{Risk}

Since higher variability in earnings indicates that the probability of bankruptcy increases, we can expect that firms with higher income variability have lower leverage (Bradley et al.,1984; Titman and Wessels, 1988). Firms that have high operating risk can lower the volatility of the net profit by reducing the level of debt. A negative relation between operating risk and leverage is also expected from a POT perspective: firms with high volatility of results try to accumulate cash during good years, to avoid under-investment issues in the future.

\subsubsection{Growth}

Following TOT, for companies with growth opportunities, the use of debt is limited as in the case of bankruptcy, the value of growth opportunities will be close to zero, growth opportunities are particular case of intangible assets (Myers, 1984; Williamson, 1988 and Harris and Raviv, 1990). Firms with less growth prospects should use debt because it has a disciplinary role (Jensen, 1986). Firms with growth opportunities may invest sub-optimally, and therefore creditors will be more reluctant to lend for long horizons. This problem can be solved by short-term financing (Titman and Wessels, 1988) or by convertible bonds (Jensen and Meckling, 1976).

Applying pecking order arguments (Titman and Wessels, (1988); Lang et al. (1996), growing firms place a greater demand on the internally generated funds of the firm. Consequentially, firms with relatively high growth will tend to issue securities less subject to information asymmetries, i.e. short-term debt. This should lead to firms with relatively higher growth having more leverage.

\subsubsection{The market-to-book ratio (M/B)}

Myers (1977) states that the market-to-book ratio (M/B) proxy is for the investment opportunity sets that firms face. Firms with higher growth would have higher bankruptcy cost, so managers might lower the debt ratio to avoid bankruptcy. Equally, firms with higher growth might need more cash to expand their business. Managers would reduce the level of debt to avoid huge interests. That is to say, the coefficient of market to book ratio is less than zero.

The market-to-book ratio = Market Value of Total Asset / Book Value of Total Asset

$=($ Book debt + market equity $) /$ Book Value of Total Asset

\subsubsection{Non-debt tax shield}

Non-debt tax shield like tax deduction for depreciation and investment tax credits are substitutes for the tax benefit of debt financing (DeAngelo and Masulis, 1980). Therefore, the tax advantage of leverage decreases when other tax deduction increases.

\subsubsection{Age}

Young firms tend to be externally financed while older tend to accumulate retained earnings so age must be negatively related to leverage (Petersen and Rajan, 1994). 


\subsubsection{Industry effect}

Since asset risk, asset type, and requirement for external funds vary by industry we could expect average debt ratios to vary from industry to industry (Myers, 1984; Harris and Raviv,1991). The sector characteristics (degree of concentration, barriers at the entry and the exit, technological changes) have an influence on the debt ratio

\subsection{Review of Empirical Studies on Determinants of financial structure Decisions for companies in Developed Economies}

The empirical literature suggests a number of factors that may influence the financial structure of companies. As argued by Titman and Wessels (1988); Harris and Raviv (1991), the choice explanatory variables in the analysis of cross-sectional variation in capital structure is fraught with difficulty. Harris and Raviv (1991) further explained that the interpretation of results must be tempered with an awareness of the difficulties involved in measuring both leverage and the explanatory variables of interest. Rajan and Zingales (1995) in their study of capital structure in the G-7 economies find gearing in the UK to be positively related to tangibility and size of the company, but negatively related to the level of profitability and the market-to-book ratio. The results of Rajan and Zingales (1995) are highly dependent upon the precise definition of gearing being examined.

Most of the empirical evidences on capital structure comes from studies of determinants of corporate ratios e.g Titman and Wessels (1988), Rajan and Zingales (1995), Graham (1996) and studies of issuing firms' debt vs. equity financing choice, Marsh (1982), Jullivand and Harris (1984), Bayless and Chaplisky (1990), Mackie-Mason (1990) and Jung (1996). These studies have successfully identified firm characteristics such as size, R and D intensity, market-to-book ratio, stock returns, asset tangibility, profitability and the marginal tax rate as important determinats of corporate financing choices. The effects associated with profitability and market-to-book ratio have been found to be especially important. Allen (1991) investigated the financial manager's perception of the broad determinants of listed companies in Australian company capital structure decisions. His results were consistent with Donaldson's (1984 )who previously reported funding in American companies; companies appear to followpecking order with respect to funding sources and also report policies of maintaining spare debt capacity. His study provides a practical explanation of why debt levels and company profitability might be inversely related. Filbecket al. (1996) tested the Patel et al. (1991) hypothesis that firms have a tendency to keep their capital structure in line with the industry and found (unlike Patel et al., 1991) virtually no support for herding behavior of firms. They only found weak support for this hypothesis and conclude that firms act rationally with respect to financing decisions.

Bervan and Daubolt (2001) examined the difficulties of measuring gearing and test the sensitivity of Rajan and Zingales (1995) results to variations in gearing measures. Based on an analysis of the capital structure of 822 UK companies, they found Rajan and Zingales (1995) results to be highly definitional-dependent. They argue that analysis of capital structure is incomplete without a detailed examination of all forms of corporate debt. The determinants of gearing appear to vary significantly, depending upon which component of debt is being analyzed

\subsection{Review of Empirical Studies on Determinant of financial structure for SME's in Developing Economies}

Most theoretical and empirical studies on capital structure have focused on large listed companies for both developed and developing countries. Since large firms can easily have access to both national and international financial markets, it could be misleading to accept and generalize the results of these studies for all types of firms. Most of these studies have been mentioned earlier on in this work. Of particular interest to us is the work of Rafiu and Akinlolu (2013) who studied capital structure determinants of non-financial firms in Nigeria using a panel of 33 large firms for a five year period to show that profitability, tangibility and company size are positively related to total debt and long-term debt, and growth opportunities are negatively associated with total debt. Because of the similarity of the terrain, we easily use their study to make comparison with our work. To our knowledge, this is the first paper that looks at the portability of the capital structure theories on small and medium sized firms in Nigeria. Other works in this area include Phlaktis et. al (2010) who conducted a study on portability of capital structure decision on small firms in developing countries around the world. Their result shows that leverage and debt maturities are lower for small firms despite their high asset tangibility and profitability ratios. Our work is clearly distinct from theirs in the sense that the firm level data of the World Bank Enterprise Survey (2002) which they used, does not take into account, the Nigerian private sector statistics. Most importantly that over the years, as revealed by the latest versions of the World Bank Enterprise Survey, there have been changes in the economic environment, business patterns and financial structure of small and medium sized businesses of developing countries of which no other study has been able to capture. In the study carried out by Rajan and Zingales (1995), to investigate capital structure decision of firms in developing countries, they used a firm level survey data for 25 countries in different stages of financial development from 
different regions. They found leverage to be positively related to tangibility but negatively related to profitability following the trade-off theory

Table 1; Summary of the implications of capital structure theories and empirical evidences on the relationship of capital structure determinants with debt;

\begin{tabular}{|c|c|c|}
\hline Determinants & Predicted sign by the theories & Sample empirical evidence \\
\hline Size & $\begin{array}{l}-\quad(\text { Pecking order }) \\
+(\text { trade-off })\end{array}$ & $\begin{array}{l}\text { Chung, (1993); Grinblatt and Titman, (1998); Rajan and } \\
\text { Zagales, (1995); } \\
\text { Titman and Wessels, (1998); Petit and Singer, (1985); Ozkan, } \\
\text { 1996) }\end{array}$ \\
\hline Asset structure & $\begin{array}{l} \pm \text { (trade-off) } \\
+ \text { (pecking order })\end{array}$ & $\begin{array}{l}\text { Myers, (1977), Hutchinson and Hunter, (1995); Long and } \\
\text { Malitz, (1985) } \\
\text { Chung, (1993); Walsh and Ryan, (1997); Harris and Raviv, } \\
\text { (1990); Berger and Udell, } \\
\text { (1998) }\end{array}$ \\
\hline Tangibility & + (pecking order) & $\begin{array}{l}\text { Rajan and Zingales (1995), MacKay and Phillips (2005) and } \\
\text { Campello (2006 }\end{array}$ \\
\hline Profitability & $\begin{array}{l}-\quad \text { (Pecking order) } \\
+\quad(\text { trade-off })\end{array}$ & $\begin{array}{l}\text { Kester, (1986); Baskin, (1989); Griner and Gordon, (1995); } \\
\text { Sunder and Myers, (1999) } \\
\text { Marsh, (1982); Rajan and Zingales, (1995); Chittenden et al. } \\
\text { (1996) }\end{array}$ \\
\hline Growth & $\begin{array}{l}\text { (trade-off) } \\
\pm \text { (pecking order) }\end{array}$ & $\begin{array}{l}\text { Jensen and Meckling, (1976); Myers, (1984); Williamson, } \\
\text { (1988); Harris and Raviv, (1990); Jensen, (1986); Titman and } \\
\text { Wessels (1988) } \\
\text { Titman and Wessels, (1988); Lang et al. (1996) }\end{array}$ \\
\hline Non-debt tax shield & - $\quad$ (trade-off) & De Angelo and Masulis, (1980) \\
\hline Age & - $\quad$ (pecking order) & Petersen and Rajan, (1984) \\
\hline Industry effect & \pm (trade-off) & Myers, (1984); Harris and Raviv, (1991) \\
\hline
\end{tabular}

Source; Author's compilation

\section{Data Sampling and Design}

The entire population of small and medium scale companies in Nigeria was categorized under five broad headings of Agriculture, Manufacturing, food and Beverage, Trading and Services

From each of these categories, two SMEs were selected to give a total of ten samples. These samples are used for a pilot survey to test the relevance and significance of variables identified in literature.

\subsection{Data Collection}

Required data on the identified variables were extracted from the financial statements of the selected companies from 2000-2009.

\subsection{Model Specification}

Similar to previous studies of Maksimovic and Zechner (1991), Williams (1995), Fries et al. (1997)). MacKay and Phillips (2005), Campello (2006), Phlakts et. al (2010) a benchmark regression model for Leverage (either market or book values) of the following form is estimated;

Leverage $_{i, t}=c+$ overall tangibility $_{i, t}+\beta X_{i, t}+\sum$ Firm $_{i}+\sum$ Year $_{t}+\mu_{i, t \ldots \ldots \ldots \ldots \ldots . . .(I)}$

Where the index i denotes a firm, the $\mathrm{t}$ denotes a year, $\mathrm{c}$ is a constant, and $\mathrm{X}$ is a matrix containing the common control variables just described (Profitability, Growth, etc.). Firm and Year absorb firm- and time-specific effects, respectively.

\subsubsection{Measurement of Variables}

Tangibility is measured as fixed assets over total assets (Titman and Wessels, 1998; Phlaktis 2010)

Growth is measured as percentage change in total assets (Titman and Wessels 1988)

Size is measured as natural log of Sales/Revenue/Turnover (Titman and Wessels 1988)

Profitability is measured as Net margin

Fixed-effects, using 25 observations

\section{Regression Result}

Included 5 cross-sectional units

Time-series length $=5$

Dependent variable: Leverage 


\begin{tabular}{|c|c|c|c|c|c|}
\hline & Coefficient & Std. Error & t-ratio & $p$-value & \\
\hline const & 0.321868 & 0.0366393 & 8.7848 & $<0.00001$ & $* * *$ \\
\hline Profitability & 0.0771944 & 0.0244929 & 3.1517 & 0.00582 & $* * *$ \\
\hline Growth & 0.0462322 & 0.069591 & 0.6643 & 0.51538 & \\
\hline Tangibility & 0.00187091 & 0.0112484 & 0.1663 & 0.86986 & \\
\hline Size & 0.02124531 & 0.0041101 & 5.1692 & 0.00161 & $* * *$ \\
\hline Mean dependent var & 0.371160 & \multicolumn{2}{|c|}{ S.D. dependent var } & & 0.299599 \\
\hline Sum squared resid & 0.280996 & \multicolumn{2}{|c|}{ S.E. of regression } & & 0.128566 \\
\hline R-squared & 0.869561 & \multicolumn{2}{|c|}{ Adjusted R-squared } & & 0.815851 \\
\hline $\mathrm{F}(7,17)$ & 16.18989 & \multicolumn{2}{|l|}{ P-value(F) } & & $2.24 \mathrm{e}-06$ \\
\hline Log-likelihood & 20.63017 & \multicolumn{2}{|c|}{ Akaike criterion } & & -25.26035 \\
\hline Schwarz criterion & -15.50934 & \multicolumn{2}{|c|}{ Hannan-Quinn } & & -22.55583 \\
\hline rho & 0.117912 & \multicolumn{2}{|c|}{ Durbin-Watson } & & 1.752089 \\
\hline
\end{tabular}

Test for differing group intercepts -

Null hypothesis: The groups have a common intercept

Test statistic: $\mathrm{F}(4,17)=25.1272$ with p-value $=\mathrm{P}(\mathrm{F}(4,17)>25.1272)=6.03589 \mathrm{e}-007$

Random-effects (GLS), using 25 observation

Included 5 cross-sectional units

Time-series length $=5$

Dependent variable: Leverage

\begin{tabular}{|c|c|c|c|c|c|}
\hline & Coefficient & Std. Error & t-ratio & p-value & \\
\hline const & 0.321825 & 0.125311 & 2.5682 & 0.01792 & $* *$ \\
\hline Profitability & 0.0771007 & 0.0247608 & 3.1138 & 0.00525 & $* * *$ \\
\hline Growth & 0.0498244 & 0.070463 & 0.7071 & 0.48728 & \\
\hline Tangibility & 0.00151241 & 0.0113956 & 0.1327 & 0.89568 & \\
\hline Size & 0.01023156 & 0.0028941 & 3.5353 & $0.00114 \quad * * *$ & \\
\hline Mean dependent var & \multicolumn{2}{|c|}{0.371160} & endent var & & 0.299599 \\
\hline Sum squared resid & \multicolumn{2}{|c|}{1.982279} & egression & & 0.300173 \\
\hline Log-likelihood & \multicolumn{2}{|c|}{-3.790606} & riterion & & 15.58121 \\
\hline Schwarz criterion & \multicolumn{2}{|c|}{20.45672} & Quinn & & 16.93347 \\
\hline
\end{tabular}

'Within' variance $=0.0165292$

'Between' variance $=0.0726077$

theta used for quasi-demeaning $=0.786622$

Breusch-Pagan test -

Null hypothesis: Variance of the unit-specific error $=0$

Asymptotic test statistic: Chi-square $(1)=31.5202$ with p-value $=1.97376 \mathrm{e}-008$

Hausman test -

Null hypothesis: GLS estimates are consistent

Asymptotic test statistic: Chi-square $(3)=5.1281$ with $\mathrm{p}$-value $=0.162654$

\section{Discussion of Findings}

Result shows that all the independent variables have a positive relationship with the dependent (leverage) thus confirming previous studies on determinants of capital structure Titman and Wessels (1988), Rajan and Zingales (1995), Graham (1996) and studies of issuing firms' debt vs. equity financing choice, Marsh (1982), Jullivand and Harris (1984), Bayless and Chaplisky (1990), Mackie-Mason (1990) and Jung (1996), the effect of profitability has been found to be especially important. According to Donaldson (1984), debt levels and company profitability are inversely related following the pecking order theory. The result of this study shows profitability for fixed and random effects to be directly and positively related to leverage at a significant level. The significance of the constant could also be interpreted to mean that some other factors outside the scope of 
this study like Business environment, GDP per capital, inflation and interest rates would have significant influence on Leverage.

Again, Rajan and Zingales (1995) in their separate study of small firms in developing economics; found leverage to be positively related to tangibility but negatively related to profitability following the trade-off theory. In this study, the main explanatory variable; Tangibility has a positive but insignificant relationship with leverage when it is working together with other variables, also when it is viewed separately; it has a positive and insignificant relationship with leverage.

Correlation Matrix Between Leverage and Profitability, Size and Growth

Correlation coefficients, using the observations 1:1 - 5:5

$5 \%$ critical value (two-tailed) $=0.3961$ for $\mathrm{n}=25$

$\begin{array}{lllccc} & \text { Leverage } & \text { Profitability } & \text { Growth } & \text { Tangibility } & \text { Size } \\ \text { Leverage } & 1.0000 & 0.2548 & 0.4717 & -0.0980 & 0.4739 \\ \text { Profitability } & & 1.0000 & -0.4506 & 0.0283 & 0.0324 \\ \text { Growth } & & & 1.0000 & -0.2972 & 0.3417 \\ \text { Tangibility } & & & & 1.0000 & 0.5437 \\ \text { Size } & & & & & 1.0000\end{array}$

The correlation table shows the level of association between the identified explanatory variables and leverage. The result shows that Profitability, Growth and Size are positively correlated with leverage while Tangibility has a negative correlation with leverage. This further reveals that as the companies' experience increase in profitability, growth and size, their leverage position has also been increasing. Their inability to acquire enough tangible assets to shore up their borrowing may have resulted in high cost of borrowing which would have made the leverage value to rise against their assets.

\section{Summary and Conclusion}

Measurement of the determinant of Capital Structure decision in firms has been highly exhausted in literature with the consensus that generally, factors like size, asset structure, tangibility, profitability, risk, growth, and markrt-to-book are some of the primary factors that will determine firm's leverage position. However, the financing activities of small and medium scale firms pose a varied dimension to some of the predictions of earlier studies. Among all the conventional variable factors that were tested for effect on leverage of small and medium firms, only profitability and size has a positive and significant value. Therefore these two are derived as the only determinant and peculiar factor for the leverage decision of SMEs in Nigeria. When compared to the study on large firms in Nigeria, profitability and size seem to be the factors that are common to both small and large firms in Nigeria. Even though leverage in these large firms have been discovered to be determined by almost all the factors predicted in theory. The study being a pilot study has revealed that capital structure decisions in small and medium scale companies in Nigeria may respond differently and in a peculiar way which may not agree with previous studies in this area. This study therefore provides a starting point for a more comprehensive study on capital structure decisions of SMEs in Nigeria with more samples from a wide range of sectors and business categories.

\section{References}

[1]. Alti,A. (2006). How persistent is the impact of market timing on capital structure?, Journal of Finance, 61,1681-1710

[2]. Baker, M., and Wurgler, J. (2002). Market timing and capital structure, Journal of Finance, 57, 1-32

[3]. Baskan, J. (1989). An empirical investigation of the pecking order theory, Financial Manager, 18, pp 26-35

[4]. Bie, T., and Haan, L. (2007). Market timing and capital structure: evidence for Dutch firms, The Economist, 155 (2), pp 183-206

[5]. Bradley, M., Jarell, G., Kim, E. (1984). On the existence of an optimal capital structure. Journal of Finance, 39 (3), pp 857-878

[6]. Brealey, R., Myers, S., and Allen, F. (2008). Principles of corporate finance (International edition ed.), UK: Mcgraw Hill

[7]. Chen, J. (2004). Determinants of capital structure of Chinese listed Companies, Journal of Business Research 57, pp 1341 - 1351

[8]. Chittenden, F., Hall, G., Hutchinson, P. (1996). Small firm growth, access to capital markets and financial structure: review of issues and an empirical investigation, Small Business Economic Review 8, pp 59-67

[9]. De-Angelo, H., and Masulis, R. (1980). Optimal capital structure under corporate and personal taxation, Journal of Financial Economics, 8, pp 3-29

[10]. Durand, D. (1959). Costs of debt and equity funds for business: trends and problems of measurement, reprinted in the management of corporate capital, Ezra Solomon (ed), The Free Press, pp 91-116

[11]. Ezeoha, A. (2008). Firm size and corporate financial leverage choice in developing economy: evidence from Nigeria, Journal of Risk Finance, 9 (4), pp. 351-364

[12]. Flannery, M., and Rangan, K. (2006). Partial adjustment and target capital structures, Journal of financial Economics, 79, pp 469506

[13]. Griner, E., and Gordon, L. (1995). Internal cash flow, insider ownership and capital expenditures: a test of the pecking order and managerial hypothesis, Journal of Business, Finance and Accounting, 22, pp 179-197 
[14]. Harris, M., and Raviv, A. (1991). The theory of capital structure, Journal of Finance, 46 (1), pp 297-355

[15]. Hovakimian, A. (2005). Are observed capital structures determined by equity market timing? Journal of Financial and Quantitative Analysis, 41, pp221-243

[16]. Jensen, M. (1986). Agency costs of free cash flow, corporate finance and take-overs, American Economic Review, 76, 323-329

[17]. Jensen, M., and Meckling, W. (1976). Theory of the firm: Managerial behaviour, agency costs and ownership structure, Journal of Financial Economics, 3, pp 305-360

[18]. Kayhan, A., and Titman, S. (2007). Firm's histories and their capital structure, Journal of financial Economics, 83, 1-32

[19]. Kester, C. (1986). Capital and ownership structure: a comparison of United States and Japanese manufacturing corporations, Financial Manager, 15, pp 5-16

[20]. Lang, L., Ofek, E., Stulz, R. (1996). Leverage, investment and firm growth, Journal of Financial Economics, 40, pp 3-29

[21]. Mahajan, A., and Tartaroglu, S. (2008). Equity market timing and capital structure: international evidence, Journal of Banking and Finance, 32, pp 754-766

[22]. Marsh, P. (1982). The choice between equity and debt: an empirical study, Journal of Finance, 37 (1), pp 121-144

[23]. Modigliani, F., and Miller, M. (1958). The cost of capital, corporation finance and the theory of investment, American Economic Review, 48, pp 655-669

[24]. Modigliani, F., and Miller, M. (1963). Corporate income taxes and the cost of capital: a correction, American Economic Review, 53, June pp 433-443

[25]. Myers, S. (1984). Capital structure puzzle, Journal of Finance, 39(3), pp 575-592

[26]. Myers, S., and Majluf, N. (1984). Corporate financing and investment decisions when firms have information that investors do not have, Journal of Financial Economics, 13, pp 187-221

[27]. Ozkan, A. (1996). Determinants of capital structure and adjustment to long run target, Journal of Business, Finance and Accounting 28, pp 175- 198

[28]. Phylaktis, K., Moradoglu, G and Bas, T. (2010). Capital Structure around the World: Are Small Firms Different? Draft Version Retreived online on 22/12/13

[29]. Rafiu, O.S and Akinlolu, A.A (2008). The Determinants of Capital Structure of Large Non-Financial Listed Firms in Nigeria, International Journal of Business and Finance Research 2(2), pp 75-84

[30]. Rajan, R., and Zingales, L. (1995). What do we know about capital structure? Some evidences from International data, Journal of Finance, 50, pp 1421-1460

[31]. Shyam-Sunder, L., and Myers, S. (1999). Testing static trade-off against pecking order models of capital structure, Journal of Finance, 51, pp 219-244

[32]. Titman, S., and Wessels, R. (1988). The determinants of capital structure choice, Journal of Finance, 43, 1-19

[33]. Williamson, O. (1988). Corporate Finance and corporate governance, Journal of Finance, 43(3), pp 567-591

[34]. Zou, H., and Xiao, J. (2006). The financing behaviour of listed Chinese firms, The British Accounting Review, 38, pp 239-258 